\section{A study on the development of materials based on local advantage: Improving elementary school students' creativity}

Arrosyad, M. Iqbal

University of Sebelas Maret Surakarta, Indonesia (arosyadiqbal@gmail.com)

Murwaningsih, Tri

University of Sebelas Maret Surakarta, Indonesia (murwaningsih_tri@yahoo.com)

Winarni, Retno

University of Sebelas Maret Surakarta, Indonesia (winarniuns@yahoo.com)

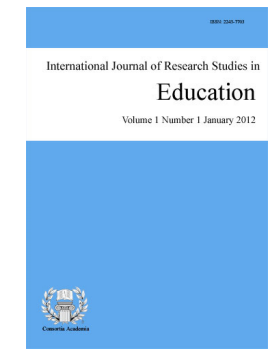

ISSN: $2243-7703$ Online ISSN: 2243-7711

OPEN ACCESS

\title{
Abstract
}

This research purpose to develop materials learning based of painting on local wisdom for grade 4 students through a handbook, consisting of teacher books and student books that can enhance student creativity. This painting material includes painting lessons with local wisdom themes and guided using correct and easily understood painting techniques by students. This instructional material is equipped with competence map to be achieved by students, description of student learning materials, exercise questions, and assessment used to measure student's competence on the result of painting and creativity. Research methods in research and development are using Borg and Gall technique. Expert validation results show teaching materials based on local wisdom to improve students' creativity valid and very feasible to use. Students' responses to an understanding of local wisdom have increased by $95 \%$. Teaching materials based on local wisdom to improve creativity can improve the competence of painting and creativity of students. The results of this study indicate that there is a significant difference between the post test of the experimental group and the control group. The pretest average of 77.63 and post-test 86.16 in the experimental group showed a significant increase of 8.53. The average of pretest control group is 68.22 and post-test 80.44 , with the value of 12.22 , it can be said that experimental group using new teaching materials is effective in improving students' painting ability.

Keywords: teaching materials; painting; local wisdom; creativity; elementary school 


\section{A study on the development of materials based on local advantage: Improving elementary school students' creativity}

\section{Introduction}

In the world of painting learning into activities that can be done by anyone, but requires the willingness and creativity, much in painting learning that initially only often practice or like to paint, but if done repeatedly will make students can paint well and even can (Pamadhi, 2009, p. 118) art is a human spiritual activity that reflects reality in a creation which its form and contents have the power to evoke certain experiences in the spiritual realm of the recipient. The ideal concept of SBK learning should be able to develop aspects of artistic cognition, art appreciation, and creative experience with balance (Sulistiyaningsih, 2013, p. 52). In the above exposure is very necessary for learning SBK, especially if associated with the ability of children to be able to use the power of thought, creativity, taste, and creativity of students that is in the field of paint for learning objectives are expected to be achieved optimally.

The painting can be appreciated from the side made by the painter, even people tend to appreciate the painting as a picture, even if observed more closely it is a painting, as revealed by (Rizky \& Sabana, 2016, p. 6) "one tends to look what's in an old mater before looking it as a picture, "whereas" one sees a modernist painting as picture First ". This is expressed by (Komarudin, Setiawa, \& Agus, 2016, p. 284) on the value of batik art "a piece of batik could appraise the greatness of Indonesian culture that is polite, cultured and civilized". By looking around and also observing in detail the colors that exist such as mountains, trees, buildings, clouds, birds, flowers, and much more, our minds will get additional information indirectly and actually at that moment are creativity of the brain. As (Buzan, 2002, p. 69) says in every second of our lives, the Great Artists in our Creative Brain have painted the perfect picture of reality for us to admire.

In art education in elementary school, art education is directed to the formation of attitudes that develop imaginative, intellectual, artistic expression, develop sensitivity to taste, skill, reason and emotional sensitivity and capable of applying technology, exhibiting and performing artwork (Depdiknas in Suwandi 2008, p. 81). Therefore the approach of education through art provides direction that art education is not as an instrument to achieve the purpose of education but must emphasize the aspect of the process not only in terms of increasing sensitivity and deep curiosity and brave attitude to innovate.

Learning to paint could be said perfect if learners have been through several stages in painting learning, such as understanding the steps of painting, understanding the colors that fit the object of the image and have a lot of experience in painting, as expressed by (Kindler, 2010, p. 14) "If one understands the art as a field of serious professional creative activity, which is subject to review and assessment by those who possess the relevant expertise and experience to make the determinations - then the idea of artistic development has to be related to the attributes and the custodians of the artistic domain.

When learning takes place between the educator and the learner must have a sense of trust with each other, the beliefs that arise must also have a good direction, as expressed by (Narelle \& Susanne, 2013, p. 9). "Beliefs about the Teaching of arts education inform a teacher's capability to teach the arts (dance, drama, media, music and visual arts). If beliefs are positive, the teachers are more likely to learn more about the classroom. It is for the reason the exploration of teacher beliefs about arts education is important. The content of local wisdom is very important in learning, there are several studies that address the need for conservation that is developed and followed up on the research, while research also shows that the use of local content in learning can increase community awareness of the importance of environmental conservation (Armesto, Rozzi, \& Ramirez, 2001, p. 877). Additionally, incorporating local contexts into biology learning will greatly assist the process of awareness raising of students and the community on the importance of nature preservation, can clarify custom rules and 
The development of materials based on local advantage: Improving elementary school students' creativity

rules about human relationships with the natural environment (Apriana, 2012, p. 6).

The orientation of art and culture subjects is to facilitate the emotional, intellectual, physical, conception, social, aesthetic, artistic and creative experience to the learners by conducting activities of appreciation and creation of various objects products around the students beneficial to human life (Ardipal, 2010, p.10). Creativity needs to be supported with the media and tools, especially in the learning of teaching materials. This learning model has advantages such as students really perceive the subject matter given and all students actively involved in the learning so as to provide direct experience for students.

\subsection{Research problem}

In practice in the field, the learning that took place in districts Pedan, Klaten is still traditional; especially in schools located in the suburbs. The available facilities and infrastructure are minimal. In addition, learning activities that advocate utilizing information technology as a medium of instruction are still rarely used. Students who attend school on average come from middle to lower family. Accordingly, teachers only utilize the book as a medium in learning (Laksana, 2014, p. 37).

In this study, the development model is not applied in its entirety. However, by Sukmadinata the steps are morphed into three stages. The first stage is a preliminary study; this stage consists of three steps, namely literature study, field survey, and preparation of the initial product. The second stage is the development of a model consisting of two steps, namely a limited trial and a wider trial. The third resistance is the Diana model test at this stage is the test phase efficacy of the product produced by using the experimental method (Sukmadinata, 2012, p. 184-187).

Development stage and validation of initial product of teaching materials to paint with local wisdom to improve creativity is established in Elementary School in districts Pedan Klaten Regency. The limited trial phase will be conducted at SD Negeri 1 Bendo by sampling 10 students. While the field trial phase will be conducted in two elementary schools in Pedan sub-district, namely SD Negeri 1 Kedungan and SD Negeri 1 Lemahireng. For the experimental class conducted in SD Negeri 2 Kaligawe and control class conducted in SD Negeri 1 Kedungan.

\section{Literature Review}

\subsection{What is teaching materials}

According to (Nurul, Hari, \& Nurbani, 2016, p. 49) Interesting learning, effective, and the efficient course requires innovative teaching materials. Therefore, teaching materials are made in order to foster learning that is interesting, effective, and efficient.

\subsection{What is painting learning}

Painting learning is a direct learning therefore in the implementations of learning it also has components as revealed (Trianto, 2011, p. 29). The main activities in an explicit instruction learning model are: (1) providing knowledge insight; (2) practice a skill by teachers with students; and (3) guidance and feedback. The painter has a broad thought and also different from the usual things not done or could be said out of everyday life, It is as expressed (Ayan, 2002, p. 182) the power of the arts partly derived from his ability to bring us out of life daily. Art encourages us to think in new ways. Visual art uses images, shapes, colors, and space to present a stack of ideas through a narrow space and in a short time. And also as expressed (John H, 2009, p. 627) "Greek vase painting, is interpreted slightly differently by different scholars; Some, for example, include painted vases from the Greek bronze age, while others do not ".

Painting form is an activity to realize the impression of a form of an object seen or observed with the aim to 
describe the form of objects that occupying a place or space. The result of drawing the form is expected to give the impression of realistic-natural, the impression is similar to the original shape of the object and displays elements of lines, shapes, colors, and other art elements in accordance with the perspective, proportion, and position (Sumanto, 2011, p. 83).

\subsection{What is local advantage}

Culture is a big part of the activity in society so it is very connected and has a big role, as expressed by (Arif Supriyadi, 2016, p. 286). "Culture is a habit or a way of living together as a whole which is owned by the community and handed down from generation to generation ". And an artwork also greatly cared and appreciated by rural and urban societies, as expressed by (Lois, Yasraf, Pribadi, \& Ninung, 2016, p. 344). "Indonesian people in many regions have been familiar with the theater for a long time. In many religious ceremonies, street theater is often included. This street performing art is appreciated by the people living in villages and cities", and also exposed by (Condro, Djuli, \& Sulbi, 2014, p. 87). Creation process in the birth of artwork does not always have to create something that does not available. But creativity demands it to produce something different from before that departs from social reality. Creativity, therefore, is a visual art created by knowledge and intellectual work born of the genius and creativity of children (Zulkifli, 2014, p. 9).

\subsection{What is creativity}

Creativity it self, as from the beginning IP Pavlop developed in physiology and also Oen many figures such as Skinner, Rollo May, and Arthur Koestler (Acep \& Aminudin, 2016, p. 235) expressed their understanding of creativity, creativities are conditional creative that describes an action Responding to stimulus outside the "stimulus capacity" itself. Thus the conditions are performed on the outside of the habit with the desired direction or out of the ordinary audience. Therefore, creativity is not pointed to actions that provide an overview or solve problems but could contrive to things that have not available before. Under these circumstances, creativity can enable something previously considered to be something of value and admiration.

\section{Design, Sampling, and Method}

The object of research and development are produced a product teaching materials, but also leads to efforts in formulating learning techniques until prepared to be used as a product model of teaching materials that could be applied to teachers and students in painting learning. Teaching materials consist of 2 books, specifically teacher book (BG) and student book (BS). The teacher's book is packed for teacher's hand in painting, while the student's book is packed as a supplement book or a book on painting learning. The preparation of these instructional materials products, based on needs analysis, through a systematic trial process in the field, is carefully observed, evaluated, discussed with stakeholders, revised until the final product is a new resource product.

The theme the students choose according to their interests, abilities, and requirement. It makes flexible and soft teaching materials used. Flexible and soft teaching materials are usually easy to apply and can be used for a long time, in different situations, according to life experiences. That is, in line with what Semiawan (2003, p. 571) expressed that "Education is reciprocated; meaning the effect of education on the surrounding environment is reciprocal". What happens in school is inseparable from the community. Elementary School in districts Pedan Klaten District used for research has similarities in curriculum, accreditation, and average scores. The curriculum of SD Negeri 1 Bendo, SD Negeri 1 Kedungan, SD Negeri 1 Lemahireng, SD Negeri 2 Kaligawe and SD Negeri 1 Troketon use KTSP curriculum, then for accreditation are medium level, and the average value of SBK learning Medium.

Borg and Gall (2003, p. 569) states that "educational R \& D is an industry-based development model in which the findings of the research are used to design new products and procedures, which are then systematically field-tested, evaluated, and refined until they meet specified criteria of effectiveness, quality, or similar 
The development of materials based on local advantage: Improving elementary school students' creativity

standards". Research and development is a basic development model which is oriented to create a new product or step systematically. Where the products used in the study developed and performed validation and evaluation accordingly it would be the effectiveness of the product in accordance with predetermined standards and quality.

The purpose of this stage is to develop prototype (initial draft) of teaching materials into teaching materials with local wisdom to improve the creativity of fourth grade students of primary school, which include: (1) the need of teaching materials for teachers and students; (2) preparation of the initial draft (prototype); (3) development of prototype of teaching materials into teaching materials; and (4) test of the effectiveness of teaching materials.

\section{Results and Discussion}

The results of the study and discussion reported in chapter IV are consistent with the research problem, i.e: (1) the necessary of teaching materials for teachers and students; (2) preparation of the initial draft (prototype); (3) development of prototype of teaching materials into teaching materials; and (4) test of the effectiveness of teaching materials.

\subsection{Teaching Materials Needs for Teachers and Students}

It's known that there are teachers who do not apply the book compiled in teaching. This is due to the unavailability of learning tools that he compiled. The fact is that: (1) the teacher does not understand how the technique of writing the teaching materials; (2) the time available to write teaching materials is only 2 weeks; (3) the lack of literature as a source for the writing of teaching materials; (4) no correction and frizz teams.

Teachers' responses - Teachers' responses to the feasibility of the old teaching materials are directed to the concept of Cunningswort (1995, p. 65), especially concerning four aspects of the development of painting skills, that is: (1) basic learning skills, (2) the existence of the development of painting skills elements as supporting components, (3) the proportion of the distribution of matter, and (4) the material content with the necessaries. Based on the data analysis from the questionnaire in the informant of the teacher as the user of the old teaching material, stated the reason to use the book because: (a) there is no other choice, only there is one book sold; (B) its content is in accordance with SBC; (C) the price of the book according to the student's pocket or student's ability; (D) a book that is easy to obtained because it is delivered directly by the marketing officer to the school.

Student Response - The response of the student informant as the user of the old teaching materials to the questions asked in evaluating the feasibility and quality of the old teaching materials can be summarized as follows: (a) the material space in the teaching materials is too short and incomplete so it is rather difficult to understand, because there are no examples the least; (B) the contents of teaching materials have not all guided or stimulated students in improving the competence of painting. This can be observed from the exercises that further lead students to paint activities, and give decoration in improving creativity. There is even a teaching material that has absolutely no casting appraisal; (C) the theme of the teaching material is irrelevant to the needs, abilities, and environment around the student; and (d) the approach teachers use in conveying material by teachers is more dominant to paint with pencils or crayons freely.

\subsection{The Result of Teaching Material Instructions Painting with Local Wisdom to Improve Student Creativity}

Prastowo (2012, p. 17) states that teaching materials are all materials (information, tools, and text) systematically arranged, showing the spirit of the competence that will be controlled by learners and used in the learning process for the purpose of planning and reviewing the implementation of learning. And also according to Majid (2011, p. 174), Teaching materials are a set of materials organized systematically so as to create an environment/atmosphere that allows students to learn well.

From the exposure in this study, the teaching materials are made in the form of textbooks consisting of 2 
Arrosyad, M. I., Murwaningsih, T., \& Winarni, R.

books, the book teacher, and student book. The teacher's book (BG) is packaged for teacher's hand in teaching which is more complete than the student's book. Student book (BS) is packaged in student activity sheet which contains various activities that students do in painting learning. Learning materials paint in teacher books relevant to the material contained in the student book.

\subsection{Limited Trial}

Based on the findings of limited trials, weaknesses, and excellence of teaching materials; the results of interviews with students and teachers as materials to determine the feasibility of draft teaching materials. The prototype design used in the limited trials generally can be said to be feasible for use in extensive trials. However, it needs to be revised from the findings and suggestions for improving the prototype so that it is even better to use a wide trial.

\subsection{Large Trial}

This extensive trial was conducted in 2 schools in Pedan sub-district of Klaten Regency, namely: SD Negeri 1 Kedungan 18 students, SD Negeri 2 Lemahireng 19 students. Student sample amounted to 37 students from two classes. Values of the students 'ability to paint in the fourth grade at SD N 1 Kedungan and SD N 2 Lemahireng using teaching materials to paint the local wisdom to improve students' creativity, that the highest value in the pretest stage is obtained by SD N 1 Kedungan with a value of 90 with the average value of 71.26, and the highest value in the post test stage obtained by SD N 2 Lemahireng with a mean value of 86.28. And also in this broad test stage the average value of pretest and post test increase, so it can be said by the existence of learning using new teaching materials influence the result of student value and also students experience development in painting material.

\subsection{Pretest - Posttest Experiment}

This experimental data analysis was conducted to compare the pretest and post test of new teaching materials by using non-independent test t. Non-independent tests were conducted to determine the significance of improving students' painting skills using new teaching materials. The significance is based on the results of pretest and post test score on new teaching materials. Before the calculation of different test or t-test is done, test data linearity as a prerequisite of a t-test. Calculation of prerequisite test conducted in this research is morality test and homogeneity test.

Test of Experiment Group Normality - Testing the formality of painting ability in experimental class using new learning material was calculated by SPSS Kolmogorov Smirnov, that the highest average was found in post test group with the average result of 86.16 and the lowest average was in protest group with average result 77.63. It indicates that the pretest and post test data are from normally distributed populations.

Test of Control Group Normality - The morality test for the ability to paint the control group using the old teaching materials was calculated by SPSS Kolmogorov Smirnov, that the highest average was found in the Post test group with the average of 80.44 and the lowest average was in the protest group with the mean of 68.22. It indicates that the pretest and post test data are from normally distributed populations.

\subsection{ANOVA one way analysis}

The test is conducted to compare two groups. Testing Hypothesis H0: $\alpha \mathrm{i}=0$ (There is no difference in experimental and control group values). Hi: there are $\alpha$ i, which is not equal to zero. (There is a difference between the value of the experimental group and the control group). Significant level $\alpha=0.05$. A statistical test of one-way variance analysis with cell frequency is not the same as using SPSS application. Detailed analysis of one way ANOVA test data by SPSS is attached. 
The development of materials based on local advantage: Improving elementary school students' creativity

Table 1

Average Results of Pretest Experiment and Control Group

\begin{tabular}{lcccl}
\hline \multicolumn{1}{c}{ Group } & Average & $d f$ & $p$ & \multicolumn{1}{c}{ Pronouncement } \\
\hline Experiment & 77.63 & 19 & \multirow{2}{*}{0.003} & There is no significant \\
Control & 68.22 & 18 & & different \\
\hline
\end{tabular}

Based on a statistical analysis result of one way ANOVA with SPSS application above shows that for a value of $p=0.003$ <significant level $=0.005$. Then stated H0 accepted. It shows indication no significant difference between experimental group pretest value and control group.

Table 2

Average Results of Post test Experiment and Control Group

\begin{tabular}{lcccl}
\hline \multicolumn{1}{c}{ Group } & Average & $d f$ & $p$ & \multicolumn{1}{c}{ Pronouncement } \\
\hline Experiment & 86.16 & 19 & \multirow{2}{*}{0.002} & There is a significant \\
Control & 80.44 & 18 & & different \\
\hline
\end{tabular}

Based on statistical analysis of one way ANOVA with SPSS application above shows that for value of $p=$ 0.002 <significant level $=0.005$. Then stated H0 accepted. It shows indications that there is a significant difference between the post test value of the experimental group and the control group.

Table 3

Average Results of Pretest and Posttest Experiment and Control Group

\begin{tabular}{|c|c|c|c|}
\hline No & Group & Pretest & Post test \\
\hline 1. & Experiment & 77.63 & 86.16 \\
\hline 2. & Control & 68.22 & 80.44 \\
\hline
\end{tabular}

Based on table 1 experimental group from SD N 1 Troketon class IV districts Pedan, Klaten using new teaching materials get pretest average value 77.63. And also control group from SD N 1 Kaligawe districts Pedan, Klaten which use old teaching material get pretest value 6.22. Pretest results in the experimental and control groups had no significant differences.

Based on table 2 experimental group from SD N 1 Troketon class IV districts Pedan, Klaten using new teaching materials get pretest average value of 86.16. And also the control group from SD N 1 Kaligawe districts Pedan, Klaten using old teaching materials get the pretest average value 80.44 . The results of the experimental and control group post test have significant differences.

Based on table 3 it can be observed that the pretest average value of the experimental group is 77.63 and the protest of the control group is 68.22. Both groups have a difference of 9.4096. It shows that pretest results have meaningless differences (almost the same). The mean of experimental posttest value 86.16 and mean of control group posttest 80.44 . This identifies that the experimental group post test score is higher than the value of the control group with the difference in the value of 5.7139 and has significant differences.

Reciprocally, the pretest average of 77.63 and posttest 86.16 in the experimental group showed a significant increase, such as 8.53. While in the control group, the average pretest result was 68.22 and posttest 80.44 , with the value of 12.22. Eventually, it can be concluded that the experimental group using new teaching materials is declared effective to improving the painting ability of elementary students in districts Pedan Klaten.

\section{Conclusion}

Teaching material needs of students and teachers in painting learning could be known through the findings of exploratory studies and literature study, therefore teachers and students need a complete teaching material and easy to understand in order to achieve learning objectives. 
Developed a prototype that has been compiled and validated and then revised for a limited trial. The result of the limited trial of teaching materials to paint the insights of local wisdom to improve the creativity of students in the fourth grade of State Primary School 1 Bendo, district Pedan, Klaten even semester from10 students obtained the average score of 4.3. The score according to Sukarno's $(2009$, p. 84) scoring guidance is included in the criteria very well. Some experimental findings were improved for extensive testing. Results of the extensive trial; the average pretest of 71.26 and average posttest of 85.37. The results of observations and findings on extensive trials were consulted with experts and revised for experimentation.

Experiments were conducted to determine the effectiveness of teaching materials. The results of the effectiveness test show that "new" teaching materials have the advantage of "old" teaching materials. The result of one way ANOVA statistical analysis with SPSS application showed that for the value of $p=0.003<$ significant level $=0.005$. Then stated $\mathrm{H} 0$ accepted. It shows indication no significant difference between experimental group pretest value and control group. Based on statistical analysis result of one way ANOVA with SPSS application shows that for value of $p=0.002<$ significant level $=0.005$. Then stated $\mathrm{H} 0$ accepted. It shows indications that there is a significant difference between the posttest value of the experimental group and the control group. The pretest average of 77.63 and posttest 86.16 in the experimental group showed a significant increase of 8.53. While in the control group, the average pretest result was 68.22 and posttest 80.44 , with the value of 12.22 . Then, it could be avowed that the experimental group using new teaching materials is declared effective in improving the ability to paint on elementary students in district Pedan, Klaten.

\subsection{Recommendations}

For more meaningful learning, teachers need to: (a) have good preparation and planning for teaching; (B) provide and can utilize media that support the learning process; (C) presenting material that goes beyond simply presenting which has existed in the teaching materials; (D) develops its professional skills to improve students' painting competencies; And (e) conducting teaching-learning activities by integrating the theme of problems that occur around the students. Intended to fourth grade elementary school students to apply the student's book in painting learning because it has been proven and tested can: (1) improve the competence of painting students in various ways; (2) motivating and enabling students in learning; (3) cultivate students' social awareness of the surrounding environment.

Intended to the next cultural arts learning researcher, to obtain: (a) develop art and cultural skills and skills in particular more creative and innovative painting (b) develop and find strategies, approaches and models that are varied and interesting for the learning of art and culture paint; And (c) develop other artistic research to enhance creativity. Development of this resource is a small part of the development of existing teaching materials. To the decision maker, specifically the local government, especially the education office of Klaten Regency, to obtain: (a) recommend that this instructional material be used in SD Klaten District because it has been tested for effectiveness, and adjusted to the needs and conditions of students; (B) provide a budget for the multiplication of teaching materials for students to have free primary school; (C) providing the facilities and infrastructure teachers necessary for the development of teaching materials; (D) conducting professional teacher enhancement activities; And (e) prioritizing 'environmental' and 'humanitarian' issues that occur to avoid conflict.

\section{References}

Abdul, M. (2011). Planning learning development of teacher competency standards. Bandung. ID: PT Remaja Rosdakarya.

Acep, I, S., \& Aminudin, T. H. S. (2016). Dimensional space in fine works. MUDRA Journal of Cultural Art, 31(2), 234-248.

Andi, P. (2012). Creative guide creating innovative instructional materials. Jogjakarta. ID: Diva Press.

Apriana, E. (2012). Integrating conservation concepts in biology learning as an effort to grow literacy and environmental awareness among students. Journal of Education Serambi Ilmu, 12(1), 1-6. 
The development of materials based on local advantage: Improving elementary school students' creativity

Ardipal, A. (2010). The curriculum of cultural art education is ideal for future learners. Language and Art Journal, 11(1), 1-10. http://doi.org/10.24036/komposisi.v11i1.69

Armesto, J. J., Rozzi, R., \& Ramirez, S. C. (2001). Conservation strategies for biodiversity and indigenous people in Chilean forest ecosystems. Journal of the Royal Society of New Zealand, 31(4), 865-877. https://doi.org/10.1080/03014223.2001.9517681

Arif, M, M., \& Supriyadi. (2016). Preservation and development strategies of Gorontalo's local culture through Gorontalo cultural digital repository application. MUDRA Jurnal Seni Budaya, 31(3), 285-294.

Ayan, J. E. (2002). Creative workshop. Bandung. ID: Mizan Media Utama.

Borg, W. R., \& Gall, J. P. (2003). Education research. New York, AS: Allyn and Bacon.

Condro, W., Djuli, D., \& Sulbi. (2014). Suwardi: Leader of puppet development in Pacitan. Journal of Fine Arts Education, 2(3), 84-90.

Cunningsworth, A. (1995). Choosing your course book. Oxford: Heinemann.

Kiki, R, S, P., \& Setiawan, S. (2016). Markers of post-conceptual painting in Bandung contemporary art: A case study on Errata-optika exhibition. MUDRA Journal of Cultural Art, 31(3), 270-276.

Kindler, A. M. (2010). What can young children learn from a/Art activities? International Art and Art in Early Childhood Research Journal, 2(1), 1-14.

Komarudin, K., Setiawa, S., \& Agus, S. (2016). Symbolic meaning of the ornamental diversity of Cirebon Batik Pegajahan. MUDRA Journal of Cultural Art, 31(3), 277-284.

Laksana, D. N. L., \& Wawe, F. (2015). Use of local culture-based media in science lesson to increase activities and understanding of primary school students' science concept. Scientific Journal of Education Citra Bakti, 2(1), 27-37.

Lois, D., Yasraf, A. P., Pribadi, W., \& Ninung, Y. D. A. (2016). Wonderful archipelago as the result of culture diaspora through carnivals in Indonesia. MUDRA Journal of Cultural Art, 31(3), 342-358.

Narelle, L., \& Susanne, G. (2013). What is the role of the arts in a primary school? An investigation of perceptions of pre-service teachers in Australia. Australian Journal of Teacher Education, 38(9), 1-9. https://doi.org/10.14221/ajte.2013v38n9.7

Nurul, Z., Hari, S., \& Nurbani, Y. (2016). IBM guru in the development of innovative creative instruction materials based on local potential. Journal of Dedication, 13(13), 39-49.

Oakley, J. H. (2009). Greek vase painting. American Journal of Archaeology, 4(113), 599-627. https://doi.org/10.3764/aja.113.4.599

Pamadhi, H., Evan, S., \& Agus, T. (2009). Art education at elementary school. Jakarta, ID: Universitas Terbuka.

Semiawan., C. R. (2003). Development of learning guides while playing scientific journal of early childhood. Director of Early Childhood Education, 2(2), 8-17.

Sukardjo, M. (2009). The foundation of concept and its application education. Jakarta,ID: Rajawali Pers. Sukmadinata, \& Nana, S. (2012). Educational research methods. Bandung, ID: PT Remaja Rosdakarya.

Sulistiyaningsih. (2013). Improved learning outcome of Nusantara mask work through explicit instruction model. JEE Journal of Elementary Education UNNES, 2(2), 51-56.

Sumanto. (2005). Development of kindergarten creativity kindergarten. Jakarta, ID: Depdikbud.

Suwandi, B. (2008). Understanding qualitative research. Jakarta, ID: Rineka Cipta.

Tony, B. (2007). Subtitle Susi Purwoko smart book mind map. Jakarta, ID: PT Gramedia Pustaka Utama.

Trianto. (2007). Innovative learning models are constructivist-oriented. Jakarta, ID: Prestasi Pustaka Publisher.

Zulkifli. (2014). Learning strategy of cultural art in school. State University of Medan, ID: The Character Building University. 
Arrosyad, M. I., Murwaningsih, T., \& Winarni, R. 